\title{
Therapeutic Communication Management at Permata Bunda Hospital, Medan
}

\author{
Helmi Syahputra ${ }^{1}$, Syukur Kholil ${ }^{2}$, Suwardi Lubis ${ }^{3}$ \\ ${ }^{I}$ Ph.D Student in State Islamic University of North Sumatera (USU), Medan, Indonesia \\ ${ }^{2}$ Lecturer in State Islamic University of North Sumatera (USU), Medan, Indonesia \\ ${ }^{3}$ Lecturer in Universitas Sumatera Utara (USU), Medan, Indonesia \\ wildanansori22@gmail.com
}

\begin{abstract}
This study aims to find out therapeutic communication management at Permata Bunda Hospital, Medan. This type of research is qualitative research. This research is conducted at Permata Bunda Hospital, Medan. The result shows that In the application in the therapeutic communication management environment that is carried out by Permata Bunda Medan Hospital, it includes: what activities will be achieved, how to implement them, with whom the implementation will be carried out, when to implement them, where and with what budget, types of activities to be carried out, duration of activities - these activities will take place, the costs of implementing those activities are provided, the income that the hospital will receive.
\end{abstract}

\section{Introduction}

Trust in health services was greatly influenced by the quality of the relationship between doctors and paramedics with patients. In the medical and nursing profession, communication between doctors and paramedics with patients is one of the competencies that must be mastered by doctors and paramedics and applied in their services in hospitals. Communication competence determines success in helping to resolve patient health problems. During this time communication competence can be said to be neglected, both in education and in practice. Good communication and take place in an equal position (not superior inferior) is needed so that patients can tell the pain / complaint they experienced honestly and clearly. Effective communication is able to influence the patient's emotions in making decisions about the next plan of action, whereas ineffective communication will invite problems.

The hospital is defined as a means of health efforts that organizes health service activities and can be utilized for the education of health workers and research. The hospital is a community forum (patient) organized by an institution in each relationship is reciprocal. The process of mutual relations between hospitals and the community is done through the usual communication between doctors and paramedics with patients. One of the paramedics is a nurse who is educated to care for the sick. Nurses are one of the important and strategic components in the implementation of health services.

In treating patients, nurses are doctors' helpers. Nurses who served as partners in carrying out their practices were put to their best use by doctors. Services provided by paramedics to patients before consulting a doctor must give suggestions to the patient to speed up the healing process, because good service greatly affects the psychological patient. 
Therapeutic communication is consciously planned communication and the goal is centered on the patient's recovery. Therapeutic communication is considered as a special and meaningful process in human relations. In nursing practice, therapeutic communication is more meaningful as the main capital in implementing nursing care. In therapeutic communication, doctors and nurses are not only required to have scientific, intellectual and technical experience helping patients, but are also supported by compassion, caring and communicating well (Machfoedz).

Doctors and nurses who have good therapeutic communication skills can establish a relationship of trust with patients, provide professional satisfaction in nursing services, and enhance the image of the nursing profession. Therapeutic communication aims to reduce the burden of feelings and fears of patients, reduce patient doubts and can affect others, the environment and himself.

Permata Bunda Hospital in Medan has a form of medical services that includes medical care and treatment. This form of service is carried out in an integrated manner in order to obtain good results, which is to help and fully develop human beings by their nature, both physically and psychologically. The vision of Medan's Permata Bunda Hospital is to provide specialist, sub-specialist services that are complete, quality, affordable and family-based. To support this vision, the mission is to provide excellent service, improve the quality of all aspects of service, and improve the education and training of health workers.

\section{Review of Literature}

\subsection{Therapeutic Communication}

Therapeutic communication is consciously planned communication, its purpose and activities focused on healing. Therapeutic communication is a shared interactive experience between nurses and patients in communication that aims to solve problems faced by patients. Therapeutic communication is an adjective associated with art and healing. Here it can be interpreted that therapeutic is anything that facilitates the healing process. Therapeutic communication or therapeutic communication is a method in which a nurse directs communication so that patients are expected to be in situations and role exchanges that can lead to beneficial social relationships.

Basically therapeutic communication is professional communication that leads to the goal of healing patients. Interpersonal communication between nurses and patients due to mutual need and prioritize mutual understanding that is planned consciously using certain expressions or cues and aims to cure the patient. Therapeutic communication is different from social communication, in that therapeutic communication always has a specific purpose or direction for communication. Therefore, therapeutic communication is planned communication. The most therapeutic communication takes place when both the patient and the nurse show respect for individuality and self-esteem. Therapeutic nurses mean that in interacting with patients or patients, these interactions facilitate the healing process. While the therapeutic relationship means that it is an interaction that has healing properties, and of course this is different from social relations.

\subsection{The Role of Paramedics (Nurses)}

Nurses are those who have the ability and authority to perform nursing actions based on the knowledge they have obtained through nursing education. A nurse is said to be professional if he has knowledge, professional nursing skills and has a professional attitude 
according to the professional code of ethics. Professional nurse profile is a comprehensive description and appearance of nurses in carrying out nursing activities according to the nursing code of ethics.

In carrying out the practice of nursing must always improve the quality of professional services by following the development of knowledge and technology through education and training in accordance with their fields of work. Nurses are required to perform their roles and functions as expected by the profession and society as users of nursing services.

A role is a set of socially expected behaviors related to individual functions in various social groups. Each individual has various roles integrated in the pattern of individual functions. A role is a set of behavior expected by another person towards someone, according to their position in a system. The role of the nurse is influenced by social conditions both from within and from outside the nursing profession and is constant.

The role of professional nurses, including: (1). care giver, as a provider of nursing care; (2) client advocate, as a defender to protect patients; (3) counselor, as a provider of patient guidance or counseling; (4) educator, as a patient educator; (5) collaborators, as members of the health team who are required to be able to work together with other health workers; (6) coordinator, as a coordinator in order to be able to utilize patient resources and potentials; (7) change agent, as a reformer who is always required to make changes; (8) consultant, as a source of information that can help solve patient problems.

In implementing the Peplau model, nurses play the following roles: (a) work partners. The nurse-patient relationship is a relationship that requires harmonious cooperation on the basis of partnership so that mutual trust, love and respect must be fostered; (b) information sources. Nurses must be able to provide accurate, clear and rational information to patients in a friendly and friendly atmosphere; (c) educator. Nurses must strive to provide education, training, and guidance to patients / their families, especially in overcoming health problems; (d) leader. Nurses must be able to lead patients / families to solve health problems through a process of collaboration and active participation of patients; (e) guardian / successor. Nurses are individuals who are trusted by patients to play the role of parents, community leaders or clergy to help fulfill their needs; and (f) counselor. Nurses must be able to provide guidance to patients' problems so that problem solving will be easier.

In nursing practice, the nurse's function must be based on scientific and humanitarian principles and be knowledgeable and skilled in carrying out nursing services and are willing to be evaluated. These are the characteristics that show the professionalism of nurses who are vital for the implementation of the functions of independent, dependent and collaborative nursing.

\subsection{Management of Organizational Communication}

Management has a very broad meaning, it can mean process, art, or science. It said the process because management there are several stages to achieve the objectives, namely planning, organizing, directing, and monitoring. It is said art because management is a way or tool for a manager in achieving goals. The application and use of management depends on each manager who is largely influenced by the conditions and the nature of the manager. It is said knowledge because management can be learned and studied the truth. Furthermore, Athoillah said that management is a process that consists of planning, organizing, directing, and controlling through the use of resources and other resources effectively and efficiently to achieve certain goals. 
According to Lee, management is an art and a science, in management there is a strategy of utilizing the energy and thoughts of others to carry out an activity directed at achieving predetermined goals. In management there are techniques that are rich in aesthetic values of leadership in directing, influencing, supervising, organizing all the components that support each other to achieve the intended goals. Meanwhile, according to Terry explained that management is a typical process consisting of planning, organizing, mobilizing, and controlling actions to determine and achieve goals through the use of human resources and other resources.

Communication management is inseparable from the demand to further ground the science of communication at the real world level. Communication management was born because of the demands to bridge the communication between theorists and communication practitioners. The theorists face limitations in applying the knowledge they have. While communication practitioners experience limitations on theoretical references or communication science. Kaye stated that communication management is how people manage their communication processes through construing meanings about their relationships with others in various settings. They are managing their communication and actions in a large relationship, some personal, some professional. According to Kaye that communication management is how people manage the communication process in relation to other people in a communication setting or context.

Communication management is a reciprocal (reciprocal) process of exchanging signals to provide information, persuade or give orders, based on the same meaning and conditioned by the context of the communicator's relationship and its social context effectively. According to Antar Venus, communication management is the process of managing communication resources aimed at improving the quality and effectiveness of message exchanges that occur in various communication contexts. The context of communication meant here means the level of individual, interpersonal, organizational, governmental, social, or even international communication. According to Diwan communication management is the process of using various communication resources in an integrated manner through the process of planning, organizing, implementing, and controlling the elements of communication to achieve the stated goals.

\section{Research Method}

This type of research is qualitative research. According to Strauss and Corbin, qualitative research is a type of research that produces findings that cannot be achieved using statistical procedures or other ways of quantification. One reason researchers use a qualitative approach is that qualitative research can uncover phenomena that occur related to the therapeutic communication strategies of doctors and medical professionals in accelerating the recovery of patients at Permata Bunda Hospital in Medan and their development, so as to find and understand what is hidden behind the phenomena that occur. happened. This research was conducted at Permata Bunda Hospital, Medan, Jl. Sisingamangaraja No. 7 Medan, Tel. (061) 736-2777, Fax. (061) 732-022. The time of the study was conducted from 9 December 2016 to April 2017. 


\section{Discussion}

In carrying out management functions, it takes an approach of human relations between members of the organization to achieve work productivity. According to Mayo, human relations is a general term used to describe the way human managers interact with their subordinates. In his research, Mayo stated that if the personnel manager motivates workers well, then human relations within the organization will be good. If morale and efficiency deteriorate, human relations in the organization become worse. To create good human relationships, managers must understand the reasons workers work in certain ways. So it is with therapeutic communication.

Therapeutic communication is a shared interactive experience between nurses and patients in communication that aims to solve problems faced by patients. In addition interpersonal communication between nurses and patients due to mutual need and prioritize mutual understanding that is planned consciously by using certain expressions or cues and aims to cure the patient. Therapeutic communication is different from social communication, in that therapeutic communication always has a specific purpose or direction for communication. Therefore, therapeutic communication is planned communication. Permata Bunda Hospital has a plan in carrying out the tasks both paramedics, doctors, and personnel to handle new patients and who have been hospitalized.

In accordance with the interview with the Head of Personnel at Permata Hospital. In terms of the planning carried out by the Hospital for new patients to cure the disease, they are:

Hospital: - Hospital comfort / facilities and infrastructure

- provision of medical devices

- provide doctors

- providing medicines

Doctor: $\quad$ - diagnose the disease correctly

- explain / communicate with the patient or the patient's family about the patient's actual condition

Paramedics: - provide nursing care

- carry out doctor's instructions

- communicate well

- be polite

Patients enter the emergency room and meet with paramedics and doctors on duty, then the doctors and nurses make a diagnosis of the patient's disease.

Viewed from Islamic communication in terms of service from leaders to subordinates, from doctors to paramedics, from doctors to patients by being sincere and the principle of merit and sin.

The principle of sincerity, a message will not have a positive impact on the communicant if it is received with a heart that is not sincere. Ikhlas according to the term means the work done by the heart to purify itself of various motives that are not true. Not willingly conveying or receiving messages means that there is no sacred desire to convey or receive messages.

The principle of sincerity is the most fundamental principle in Islamic communication. The loss of this principle from the communicator and the communicant will make the main purpose of communication, namely worship, be lost and the strength of the message faded. 
The loss of this principle from one party will hamper the communication process, let alone meet the communicator's lack of sincerity with the communicant.

Principle of Reward and Sin. This principle explains that every message or statement that comes out that contains the consequences of reward or sin. Oral has a key role in communicating, whether it leads us to success or destruction. In order not to be a means of gathering sin but always producing merit, Islam guides humans, especially their people, to take the following steps: (1) Islam forbids saying dirty and rude; (2) provide motivation to always say good.

Thereby therapeutic communication goes with hope, so that the patient's recovery, in addition through treatment (eating medicine), healing through words that encourage (motivation) to the patient. In terms of supervision carried out by Permata Bunda Hospital for patients and hospitals for doctors, and hospitals for medical staff, personnel are adjusted to the existing SOP.

Controlling or supervision is the discovery and application of ways and tools to ensure that the plan has been carried out in accordance with the plan that has been determined. The stages of supervision consist of: (1) determination of standards; (2) determining the measurement of activity implementation; (3) measuring the implementation of activities; (4) comparing implementation with standard and deviation analysis; and (5) taking corrective actions if necessary.

1. Determination of standards is according to the plan and implementation determined by the hospital to doctors, paramedics and personnel in terms of service to patients.

2. Determination of measuring the implementation of activities. The hospital facilitates facilities and infrastructure in terms of implementing patient care. In this case the doctor in treating patients holds meetings (control) to the patient accompanied by paramedics to find out how far the patient's health.

3. Measurement of the implementation of activities. In measuring the patient's recovery done by a doctor, and paramedics if the patient has seen improved by inviting patients to communicate about complaints that exist with the patient's family.

4. Comparative implementation with standard and deviation analysis. In terms of healing patients, doctors, nurses compare before and after treatment how far the development of the disease suffered by patients. In analyzing patients' illnesses, doctors and nurses are given da ily to hospitalized patients through the stages of checking.

5. Taking corrective actions if necessary. In this case doctors and paramedics when patients enter through the emergency room have abnormalities about the disease suffered by patients, doctors and paramedics provide action through discussion to the patient's family.

In addition to supervision, there are other types of supervision: (1) Feedforward control is designed to anticipate problems and deviations from the standard objectives and allow corrections before a certain activity is completed; (2) Concurrent control is a process in certain aspects of a procedure that must be approved before an activity is continued or to ensure the accuracy of the implementation of an activity; and (3) Feedback control measures the results of an activity that has been carried out.

Tompkins and Cheney are interested in how communication can produce oversight or control of employees. According to them, the organization uses the control of its members through 4 (four) ways consisting of: simple, technical, birakrasi, and consistent supervision. First, simple supervision, namely supervision that uses power directly and openly. Second, technical supervision, namely supervision using equipment or technology. For example, if a 
company provides mobile phone facilities to employees and they are asked to use mobile phones for work purposes, then the employees are actually controlled or technically supervised. In other words, they are willing to be contacted (controlled) anywhere and anytime. Third, bureaucratic supervision, namely supervision through the use of various formal procedures and rules. Examples of bureaucratic supervision can be seen from various company regulations that must be obeyed by employees. In addition, memos, reports, meeting decisions, and performance reviews are also forms of regulations that must be obeyed. Fourth, consistent supervision, namely: supervision that uses interpersonal relationships and cooperation between members of the organization or employees as a tool for controlling. Concertive supervision is the most difficult form of control to see because it relies heavily on reality and shared values. In organizations or companies that use consistent supervision, various explicit written rules generally do not function and are replaced by a shared understanding of values, goals, and ways of achieving performance accompanied by a deep appreciation of the organization's mission.

According to Tompkins and Cheney, an organization at this stage means that it has acquired what is called the "new organizational spirit". In concertive supervision, discipline is created by normalizing behavior, which is to do certain ways in order to work normally and naturally. A good example of this is the unwritten rule on how to dress. In the discipline of disciplinary supervision strengthens the relationship of power. Discipline is not seen as an obligation but as something normal and natural.

Thus the management of communication at Permata Bunda Hospital towards doctors and paramedics and personnel to handle new and hospitalized patients is adjusted to operational standards (SOP). The doctor-patient relationship is the foundation in medical practice and also medical ethics states "Patient health will always be my first consideration" and the International Medical Ethics Code states: "Doctors must give their patients full loyalty and all the knowledge they have". Traditional interpretations of the doctor-patient relationship are like a paternal relationship where the doctor makes a decision and the patient can only accept it. But this time it was no longer acceptable both ethically and legally. Because many patients are unable or unwilling to make health care decisions for themselves, patient autonomy is sometimes very problematic. Other aspects of the relationship are equally problematic, such as the doctor's obligation to maintain patient confidentiality in the era of computerized medical records and management of care and the doctor's duty to preserve life, while at the same time getting requests to accelerate death.

Appreciation and the same treatment. The belief that all humans deserve equal respect and treatment is actually something new. Some people still think that not respecting, unequal treatment of a person or group of people is still acceptable. Slavery was one until the 19th century and still exists in several parts of the world. The end of institutional discrimination against non-white people in a country like South Africa has just happened. Women still accept a lack of respect and are treated unequally in many countries. Discrimination due to disability, or because of sexual orientation is still common. So clearly there is still a lot of contradiction in the claim that people should be treated the same.

\section{Conclusions}

In the application in the therapeutic communication management environment that is carried out by Permata Bunda Medan Hospital, it includes: what activities will be achieved, how to implement them, with whom the implementation will be carried out, when to implement them, where and with what budget, types of activities to be carried out, duration of 
activities - these activities will take place, the costs of implementing those activities are provided, the income that the hospital will receive.

\section{References}

Aliah. 2010. Analisis Perbedaan karakteristik Sosial Ekonomi terhadap Persepsi Pelayanan di Instalasi Rawat Inap RSUD Labuang Baji Makassar. Skripsi. Universitas Hasanuddin.

Ali bin Muhammad bin Ali al-Zain al-Syari Al-Jurjani. 1403-1983. al-Ta'rifat, cet. 1. Beirut: Da al-Kutub al-Ilmiyyah.

Alwasila, A. Chaedar. 1985. Sosiologi Bahasa. Bandung: Angkasa.

As'ad. 1994. Sumber Daya Seri Ilmu : Psikologi industri, Edisi Ke-4.

Athoillah, Anton. 2010. Dasar-Dasar Manajemen. Bandung: CV Pustaka Setia.

Devito, Joseph A. 2001. The Interpersonal Communication Book. New York: Addison Wesley Longman.

Diwan, Parag. 1999. Management Principles and Practices. Dehradun: University of Petroleum \& Energy Studies.

Collins Publishers.

Didin \& Hendri. 2003. Manajemen Syari'ah dalam Praktik. Jakarta : Gema Insani.

Effendy, Onong Uchjana. 1992. Dinamika Komunikasi. Bandung: Citra Aditya Bakti. 1992. Spektrum Komunikasi, Bandung: Mandar Maju.

1993. Human Relations and Public Relation. Bandung: Mandar Maju. 2006. Ilmu Komunikasi Teori dan Praktek. Bandung: PT. Rosdakarya.

Fajar, Marhaeni. 2009. Ilmu Komunikasi:Teori dan Praktik. Jakarta: Universitas Mercu Buana.

Fill, Chris. Marketing Communication. Diunduh https://books.google.co.id/books/ about/Marketing_Communications.html?id=CZR9QgAACAAJ\&redir_esc=y,

Morissan. 2013. Teori Komunikasi: Individu Hingga Masa. Jakarta: Kencana.

Northouse, Peter G. 1998. Health Communication: Strategies for Health Professionals, 4th Edition. New York: Paperback.

Nurjannah, Intansari. 2001. Hubungan Terapeutik Perawat dan Klien: Kualitas Pribadi sebagai Sarana. Yogyakarta: PSIK-FK UGM.

2005. Komunikasi Terapeutik: Dasar-Dasar Komunikasi Bagi Perawat. Yogyakarta: Mocomedia.

Ruslan Rusady. 2007. Manajemen Public Relations \& Media Komunikasi Konsepsi dan Aplikasi. Jakarta: PT. RajaGrafindo Persada.

R.L Barker, R. 1987. The Social Work Dictionary, Silver Spring. MD: National Association of Social Workers.

Survei Global. 2007. Hubungan Komunikasi Dokter, Paramedis dengan Pasien.

Undang-Undang No. 23 Tahun 1992 tentang Kesehatan, LNRI tahun 1991 No. 100 TLNRI No. 349).

Undang-Undang Republik Indonesia Nomor 44 Tahun 2009 Tentang Rumah Sakit. Jakarta: Kemenkes.

Usman, Husaini. 2012. Manajemen: Teori, Praktik, dan Riset Pendidikan. Jakarta: Bumi Aksara

Venus, Antar. 2009. Manajemen Kampanye. Bandung: Simbiosa Rekatama Media. 